\title{
SYNTHESIS OF ANTIBACTERIALLY ACTIVE SILVER NANOPARTICLES BY GALVANIC REPLACEMENT ON MAGNESIUM IN SOLUTIONS OF SODIUM POLYACRYLATE IN AN ULTRASOUND
}

\author{
Galyna Zozulya ${ }^{1}$, Orest Kuntyi ${ }^{1,}{ }^{\otimes}$, Roman Mnykh ${ }^{1}$, Martyn Sozanskyi ${ }^{1}$
}

https://doi.org/10.23939/chcht15.04.493

\begin{abstract}
Green" synthesis of silver nanoparticles (AgNPs) by a galvanic replacement (GR) on magnesium in solutions of sodium polyacrylate $(\mathrm{NaPA})$ under ultrasound $(42 \mathrm{kHz})$ is reported. The mechanism of combined action of GR and ultrasound on the formation of nanoparticles is proposed. Synthesized solutions of AgNPs are characterized by an absorption maximum at $410 \mathrm{~nm}$, the value of which does not depend on the concentrations of precursors $\left(\mathrm{AgNO}_{3}\right.$ and $\left.\mathrm{NaPA}\right)$ and the duration of the process. The dimensions of nanoparticles that have a spherical shape do not exceed $30 \mathrm{~nm}$. With increasing concentration of surfactant, there is a tendency to decrease in size. The rate of synthesis of AgNPs increases almost in proportion to the concentration of $\mathrm{AgNO}_{3}$ in the solution, while the effect of NaPA concentration is negligible. The synthesized nanoparticles efficiently demonstrated a bactericide effect on Escherichia coli and Staphylococcus aureus.
\end{abstract}

Keywords: silver nanoparticles, ultrasound, galvanic replacement; magnesium, sodium polyacrylate.

\section{Introduction}

Galvanic replacement (GR) in the last decade is considered as a promising method in chemical nanomaterials for modification of metal nanostructures of the surface of metals [1-3] and semiconductors [4-6], to obtain nanoparticles [7, 8] and nanostructures [9-11]. For intensification of synthesis and design of nanoparticles and nanostructures, GR in the ultrasonic field is effective [12-23], which is the most studied for nobel metals (Table 1). Among them, silver nanoparticles (AgNPs) occupy a special place due to their high antibacterial activity and, accordingly, wide application in medicine $[24,25]$. The modern methods of obtaining them include the following

\footnotetext{
${ }^{1}$ Lviv Polytechnic National University,

12, Bandery St., Lviv, 79013, Ukraine

凶kunty@ukr.net

(C) Zozulya G., Kuntyi O., Mnykh R., Sozanskyi M., 2021
}

main criteria: 1) controlled formation by geometry (shape and size) of nanoparticles; 2) "green" synthesis; 3) manufacturability. The need for the first criterion is due to the fact that the functional properties of AgNPs significantly depend on their geometry [26-28]. Since the formation of nanoparticles is a multifactorial process [28-30], their design is mainly empirical. The "green" synthesis of AgNPs includes methods based on the use of non-toxic precursors (chemical reducing agents and surfactants), including substances of natural origin [31, 32]. The "green" synthesis of AgNPs also includes electrochemical methods [33-35]. Manufacturability covers, in addition to the previous two criteria, the high rate of synthesis of AgNPs and the low cost of the product.

Taking into account these criteria, the aim of the proposed work is to establish the laws of synthesis of silver nanoparticles by a galvanic substitution of Argentum ions with magnesium in the solutions of sodium polyacrylate in the ultrasonic field. Considering the non-toxicity of polyacrylate and magnesium ions, as well as their low cost, such studies are relevant in terms of creating the foundations of "green" technologies of metal nanoparticles.

\section{Experimental}

The research was carried out in the following directions: i) synthesis of solutions of silver nanoparticles stabilized by a polyacrylate anion, galvanic substitution in the field of ultrasound; ii) determination of their main characteristics - absorption spectra, nanoparticle sizes, and establishment of antibacterial activity.

For the synthesis of AgNPs solutions by a galvanic substitution, the following precursors were used: $\mathrm{AgNO}_{3}$ (99.9\%, Alfa Aesar), magnesium scrap (99.5\%, Alfa Aesar) with fractional composition of $0.75-1.0 \mathrm{~mm}$ and sodium polyacrylate with $\mathrm{MW}=2000(45 \%$ aqueous solutions, Sigma-Aldrich) (highlighted in red). Magnesium scrap before experiments was etched in $1 \mathrm{M}$ acetic acid solution to remove the oxide from the surface, washed with isopropanol, and dried in an airstream at $333 \mathrm{~K}$. 


\section{Conditions for the synthesis of nanoparticles - metal (MNPs) and bimetal $\left(\mathrm{M}_{1} \mathrm{M}_{2} \mathrm{NPs}\right)$} by galvanic substitution in an ultrasonic field

\begin{tabular}{|c|c|c|c|c|c|c|c|c|}
\hline MNPs & $\mathrm{M}_{1} \mathrm{M}_{2} \mathrm{NPs}$ & $\begin{array}{c}\text { Sacrificial } \\
\text { metal }\end{array}$ & $\begin{array}{l}\text { Precursor } \\
\text { of MNPs }\end{array}$ & $\begin{array}{c}\text { Ulrasonic } \\
\text { parameters }\end{array}$ & $T, \mathrm{~K}$ & $\begin{array}{c}\text { Time of } \\
\text { GR }\end{array}$ & $\begin{array}{c}\text { Size of NPs, } \\
\mathrm{nm}\end{array}$ & Ref. \\
\hline AgNPs & - & $\mathrm{Cu}$ & $\mathrm{Ag}_{2} \mathrm{O}$ & $80 \mathrm{~W}$ & 303 & $5 \mathrm{~min}$ & $10-80$ & [12] \\
\hline $\begin{array}{c}\text { AgNPs, } \\
\text { Agnanodendrites }\end{array}$ & - & $\mathrm{Cu}$ sheet & $\mathrm{AgNO}_{3}$ & $40 \mathrm{kHz}$ & $295 \pm 2$ & $10 \mathrm{~min}$ & 100 & [13] \\
\hline AuNPs & - & Ag plate & $\mathrm{H}\left[\mathrm{AuCl}_{4}\right]$ & $135 \mathrm{~W}$ & $295 \pm 2$ & $10 \mathrm{~min}$ & $30-60$ & [14] \\
\hline AuNPs & & $\mathrm{Cu}$ foil & $\mathrm{H}\left[\mathrm{AuCl}_{4}\right]$ & $42 \mathrm{kHz}$ & & $5 \min$ & 10 & [15] \\
\hline PdNPs & - & Cu NWs & $\mathrm{PdCl}_{2}$ & & $295 \pm 2$ & $1 \mathrm{~h}$ & 150 & [16] \\
\hline PtNPs & - & Fe foils & $\mathrm{H}_{2}\left[\mathrm{PtCl}_{6}\right]$ & $42 \mathrm{kHz}$ & & $10 \min$ & 10 & [15] \\
\hline RuNPs & - & Mg foil & $\mathrm{RuCl}_{3}$ & $42 \mathrm{kHz} 70 \mathrm{~W}$ & & $4 \min$ & $3.1 \pm 0.9$ & [17] \\
\hline- & Pd-AgNPs & $\mathrm{Ag}$ & $\mathrm{PdCl}_{2}$ & $40 \mathrm{MHz}$ & 298 & $5 \mathrm{~min}$ & $2-3$ & [18] \\
\hline- & $\mathrm{Pd} @ \mathrm{Pt} / \mathrm{CNPs}$ & $\mathrm{Pd}$ & $\mathrm{H}_{2}\left[\mathrm{PtCl}_{6}\right]$ & $20 \mathrm{kHz}$ & $298 \pm 1$ & $20 \mathrm{~min}$ & $3-5$ & [19] \\
\hline- & $\begin{array}{l}\text { CuAg nano- } \\
\text { powder }\end{array}$ & CuNPs & $\mathrm{Ag}_{2} \mathrm{O}$ & $100 \mathrm{~W} / \mathrm{cm}^{-2}$ & $295 \pm 2$ & - & $5-10$ & [20] \\
\hline- & $\begin{array}{l}\text { PtCuNPs/ } \\
\text { NCNT }\end{array}$ & $\begin{array}{c}\text { CuNPs/ } \\
\text { NCNT }\end{array}$ & $\mathrm{Pt}\left(\mathrm{NO}_{3}\right)_{2}$ & $\begin{array}{c}100 \mathrm{~W}, 20 \\
\mathrm{kHz}\end{array}$ & $22 \pm 2$ & $3 \mathrm{~min}$ & $\leq 5$ & [21] \\
\hline- & Ni@PtNPs & Ni@PtNPs & $\mathrm{Pt}(\mathrm{acac})_{2}$ & $20 \mathrm{kHz}$ & $22 \pm 2$ & $3 \mathrm{~h}$ & $3-4$ & [22] \\
\hline
\end{tabular}

The synthesis of AgNPs was performed in a thermostated beaker with a solution of sodium polyacrylate and $\mathrm{AgNO}_{3}$, which is placed in an ultrasonic bath (Jeken Codyson CD-4800, $70 \mathrm{~W}$ output and $42 \mathrm{kHz}$, the volume of the reservoir is $1.4 \mathrm{dm}^{3}$ ). Working volume is $100 \mathrm{ml}$. A portion of the magnesium scrap was poured into the NaPA solution, after which an ultrasonic bath was turned on. Periodically $(2,5,7,10,15,20$, and $30 \mathrm{~min})$ the solution samples were taken for the study of UV-vis spectra. After completion of the experiment, magnesium scrap was separated from AgNP solution by decantation. The latter ones were stored in closed glass tubes placed in containers.

The synthesis of AgNPs was performed at $298 \mathrm{~K}$ and concentrations of $\mathrm{AgNO}_{3} 0.2-0.8 \mathrm{mM}, \mathrm{NaPa} 1-5 \mathrm{~g} \cdot \mathrm{l}^{-1}$.

The UV-vis spectra of the colloidal solutions containing silver particles were recorded by UV/vis spectrophotometer ULab 108UV (ULab, China) using $1 \mathrm{~cm}$ cuvette at the wavelength range of $190-1100 \mathrm{~nm}$. The comparison solution is distilled water.

TEM images of the samples were recorded using a JEM-I230 (JEOL, Tokyo, Japan), which was operating at an accelerating voltage of $80 \mathrm{kV}$. TEM grids were preliminary supplied by a formvar film which then fixed by carbon using a JEE-4X vacuum evaporator (JEOL, Tokyo, Japan). Small drops (0.01-0.05 $\mu$ l) of the silver compositions were applied to grids under the light microscope and were dried in air at room temperature. The size of obtained AgNPs was determined using TEM images by comparison of the sizes of individual particles with the scales presented on images.
The antibacterial activity of AgNPs was evaluated against gram negative Escherichia Coli (E. coli) and gram positive bacteria Staphylococcus aureus (S. aureus). To do this, the bacteria were inoculated into Petri dishes with a solid selective nutrient medium for each species of microorganisms: yellow-salt agar - for the culture of $S$. aureus and Endo agar - for the culture of E. coli. Inoculation was performed after 1, 6, 18 and $48 \mathrm{~h}$ of contact of bacteria with $0.8 \mathrm{~mm}$ solution of AgNPs. All the biological material was incubated at $310 \mathrm{~K}$ for $24 \mathrm{~h}$ in a bacteriological incubator. Antibacterial activity was indexed by counting the number of microorganisms $\left(\mathrm{CFU} \cdot \mathrm{ml}^{-1}\right)$. The method of colony counting was used to count the number of viable microorganisms.

\section{Results and Discussion}

The synthesis of metal nanoparticles by the galvanic substitution in the ultrasonic field has the following features. Reduction of ions $\mathrm{M}_{2}^{\mathrm{n}+}$ occurs simultaneously by a sacrificial metal $\mathrm{M}_{1}$ by reaction (1), which takes place by the electrochemical mechanism, and by radicals and chemical reducing agents (2). The latter ones are formed due to the sonochemical decomposition of water (3) and the interaction of radicals with each other $(4,5)[36,37]$. In the presence of organic substances in the solution, radicals R. (6) are also formed [35].

$$
\begin{gathered}
\mathrm{mM}_{2}^{\mathrm{n}+}+\mathrm{nM}_{1} \leftrightarrow \mathrm{mM}_{2}+\mathrm{nM}_{1}^{\mathrm{m}+} \\
\mathrm{M}^{\mathrm{n}+}+\text { reducing radicals }\left(\mathrm{H}_{2} \mathrm{O}_{2}, \mathrm{O}_{2}\right) \rightarrow \mathrm{M}^{0} \\
\left.\mathrm{H}_{2} \mathrm{O}\right) \\
\mathrm{HO} \cdot+\mathrm{H} \cdot+\cdot \mathrm{OH} \rightarrow \mathrm{H}_{2} \mathrm{O}_{2}
\end{gathered}
$$




$$
\begin{gathered}
\mathrm{HO}_{2} \cdot+\cdot \mathrm{O}_{2} \mathrm{H} \rightarrow \mathrm{H}_{2} \mathrm{O}_{2}+\mathrm{O}_{2} \\
\mathrm{RH}+\cdot \mathrm{OH}(\cdot \mathrm{H}){ }^{\prime} \rightarrow \mathrm{R} \cdot+\mathrm{H}_{2} \mathrm{O}\left(\mathrm{H}_{2}\right)
\end{gathered}
$$

Magnesium as a sacrificial metal $\left(\mathrm{E}_{\mathrm{Mg}^{2+} / \mathrm{Mg}}^{0}=\right.$ $=-2.36 \mathrm{~V})$ provides a high value of $\Delta E$ $\left(\Delta \mathrm{E}=\mathrm{E}_{\mathrm{M}_{2}^{\mathrm{n+}} / \mathrm{M}_{2}}-\mathrm{E}_{\mathrm{Mg}^{2+} / \mathrm{Mg}}\right)$ of the process (1). This makes it possible to precipitate with the galvanic substitution nobel [38] and non-ferrous metal [39, 40] at high speed. In $\mathrm{AgNO}_{3}$ and NaPA solutions in the ultrasound field, silver does not precipitate on the magnesium surface. At a wide range of precursor concentrations, the formation of yellow AgNPs solutions with an absorption maximum of $\sim 410 \mathrm{~nm}$ is observed (Fig. 1). This can be explained by the simultaneous action of surfactant $\left(\mathrm{PA}^{-}\right)$and ultrasound. Polymeric ions $\mathrm{PA}^{-}$, containing functional groups $\mathrm{COO}^{-}$, form surface complexes on the magnesium surface. This is due to the donor-acceptor interaction between the electron pair (:) of the electron donor atom of oxygen and the free electron orbital $(\square)$ of the magnesium atoms $\left(\mathrm{COO}^{-}\right): \rightarrow \square \mathrm{Mg}$. As a result, the surface of magnesium is blocked, which complicates the process of galvanic substitution (1). The latter occurs in ultrasound due to the partial desorption of $\mathrm{PA}^{-}$ions on the magnesium surface. Moreover, there is a process of generating electrons by reaction (7) at the anode sites, which initiates the cathodic reduction of silver. Since $\mathrm{AgNO}_{3}$ in NaPA solutions, due to the electron donor properties of the polymeric anion $\mathrm{PA}^{\mathrm{n}-}$ forms complexes $\left[\mathrm{Ag}_{\mathrm{m}} \mathrm{PA}\right]^{(\mathrm{n}-\mathrm{m})-}$, the reduction at the cathode sites $(8)$ can be represented as the formation of nanoclusters $\left[\operatorname{Ag}(0)_{m} P A\right]^{\mathrm{n}-}$. At the same time, $\left[\mathrm{Ag}_{\mathrm{m}} \mathrm{PA}\right]^{(\mathrm{n}-\mathrm{m})-}$ is reduced in the volume of the solution by radicals formed by sonochemical reactions (3-6). at the anode sections:

$$
\mathrm{m} / 2 \mathrm{Mg} \rightarrow \mathrm{m} / 2 \mathrm{Mg}^{2+}+\mathrm{me}
$$

at the cathode sections:

$$
\left[\mathrm{Ag}_{\mathrm{m}} \mathrm{PA}\right]^{(\mathrm{n}-\mathrm{m})^{-}}+\mathrm{me} \rightarrow\left[\mathrm{Ag}(0)_{\mathrm{m}} \mathrm{PA}\right]^{\mathrm{n}-}
$$

During the synthesis of AgNPs by the galvanic substitution, the maximum absorption $\left(\lambda_{\max }=410 \mathrm{~nm}\right)$ of the UV-vis spectra does not shift (Fig. 2). It also does not shift during the long-term storage of such solutions.

The size of AgNPs in the process increases (Fig. 3), but their size does not exceed $30 \mathrm{~nm}$. The small size is caused primarily by the action of ultrasound. As shown in [41], the cavitation field generated by the hydrodynamic emitter covers the entire reaction volume. This, in turn, accelerates the reduction of $\mathrm{Ag}$ (I) by radicals (2) in the volume of the solution and electrochemical reactions $(7,8)$ during galvanic substitution on the magnesium surface. The consequence of this is the predominance of the rate of nucleation over growth and, accordingly, the small size of AgNPs is stabilized by the polyacrylate anion as a surfactant.

The rate of AgNPs synthesis increases almost in proportion to the concentration of $\mathrm{AgNO}_{3}$ in the solution (Fig. 4). This suggests that the total process, which includes the ultrasound galvanic substitution of magnesium and sonochemical reduction of $\left[\mathrm{Ag}_{\mathrm{m}} \mathrm{PA}\right]^{(\mathrm{n}-\mathrm{m})-}$, is of the first order. Since the size of AgNPs is practically independent of the concentration of $\mathrm{AgNO}_{3}$, the latter can be considered as a factor influencing the density of the overall synthesis process.

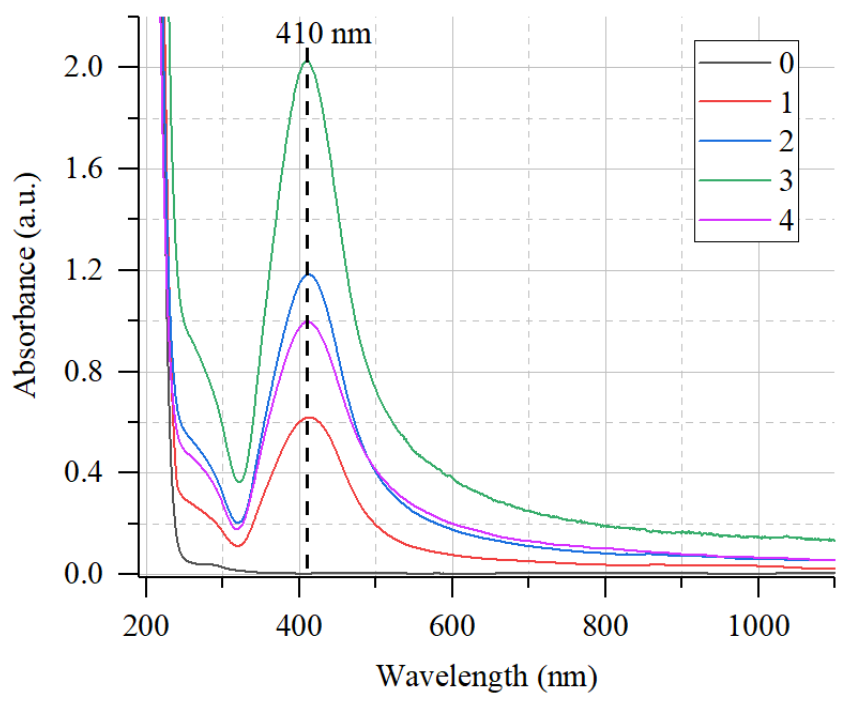

a)
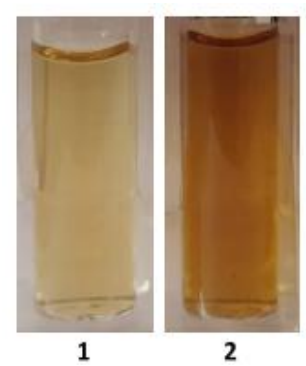

2

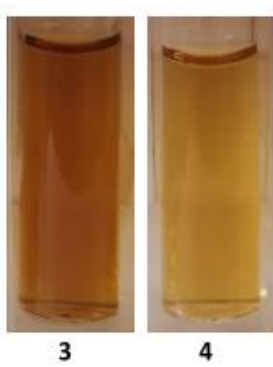

b)

Fig/ 1. UV-Vis absorption spectrum (a) and images (b) of AgNPs in NaPA solutions after galvanic replacement of magnesium in the field of ultrasound for $30 \mathrm{~min}, 0.5 \mathrm{~g}$ magnesium scrap: $\mathrm{NaPA}(0) ; 0.2 \mathrm{mM} \mathrm{AgNO}_{3}$ and $5 \mathrm{~g} \cdot \mathrm{l}^{-1} \mathrm{NaPA}^{(1)} ; 0.4 \mathrm{mM} \mathrm{AgNO}_{3}$ and $5 \mathrm{~g} \cdot \mathrm{l}^{-1} \mathrm{NaPA}(2) ; 0.8 \mathrm{mM} \mathrm{AgNO}_{3}$ and $5 \mathrm{~g} \cdot 1^{-1} \mathrm{NaPA}(3) ; 0.4 \mathrm{mM} \mathrm{AgNO}_{3}$ and $2.5 \mathrm{~g} \cdot \mathrm{l}^{-1} \mathrm{NaPA}(4)$ 


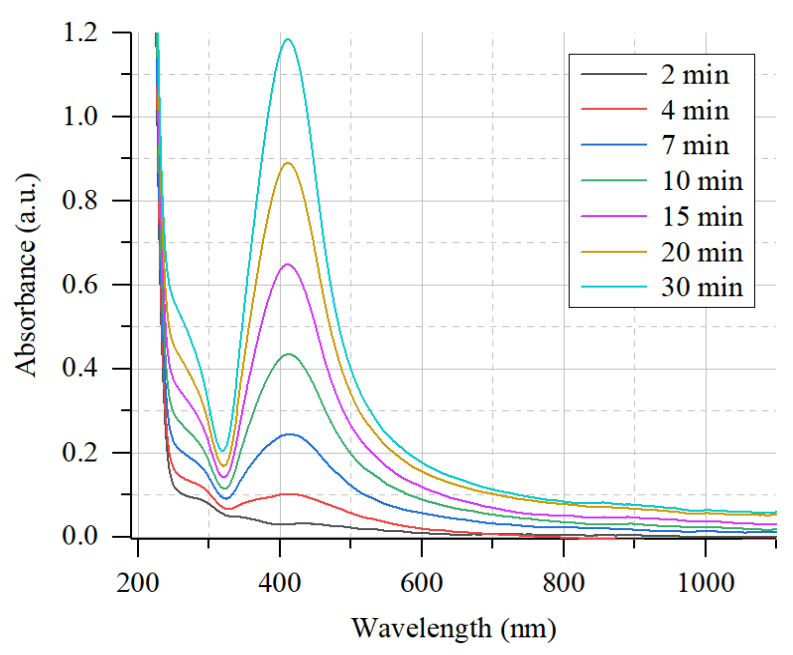

a)

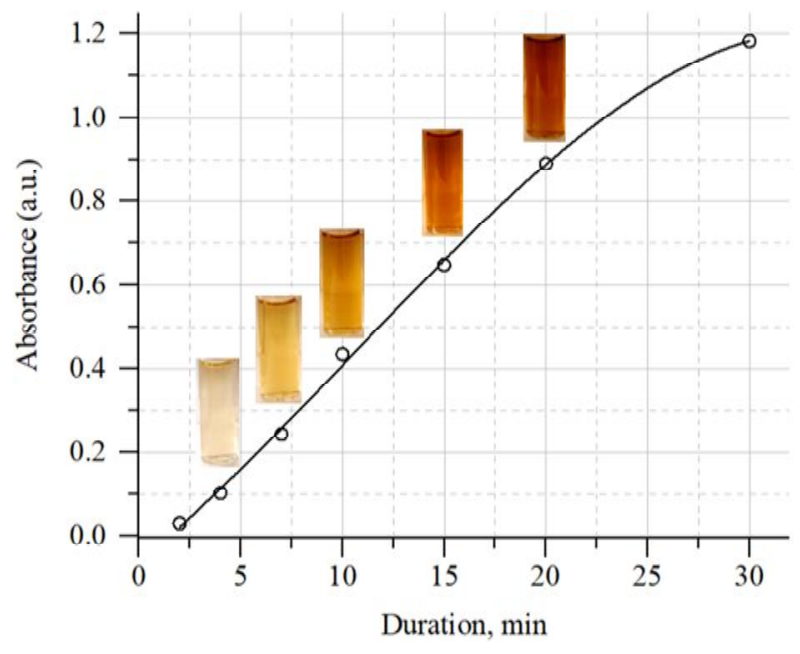

b)

Fig/ 2. UV-Vis absorption spectrum (a) and dynamics intensity (b) of maximum absorption (410 nm) in UV-Vis spectrum and color of AgNPs in NaPA solutions $5 \mathrm{~g} \cdot \mathrm{l}^{-1}, 0.4 \mathrm{mM} \mathrm{AgNO}$

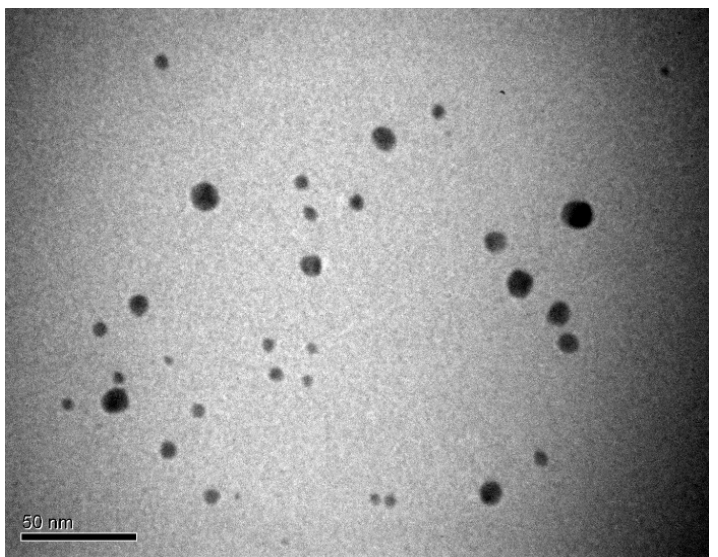

a)

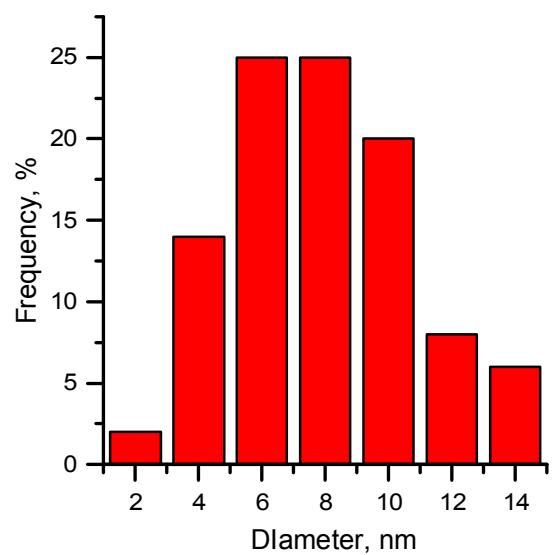

a')

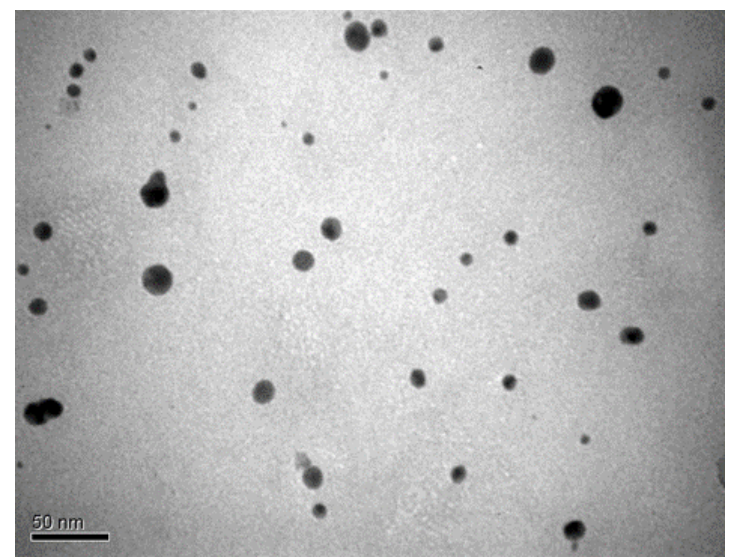

b)

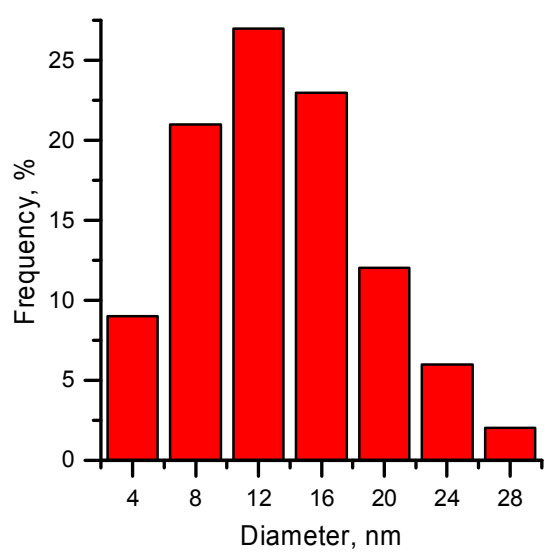

$\left.b^{\prime}\right)$

Fig. 3. TEM images $(a, b)$ and the size distribution histograms $\left(a^{\prime}, b^{\prime}\right)$ of AgNPs, synthesized in NaPA solution $\left(5 \mathrm{~g} \cdot 1^{-1}\right)$, $0.4 \mathrm{mM} \mathrm{AgNO}_{3}$ after galvanic replacement of magnesium in the ultrasound field for $10\left(\mathrm{a}, \mathrm{a}^{\prime}\right)$ and $30\left(\mathrm{~b}, \mathrm{~b}^{\prime}\right) \mathrm{min}$ 


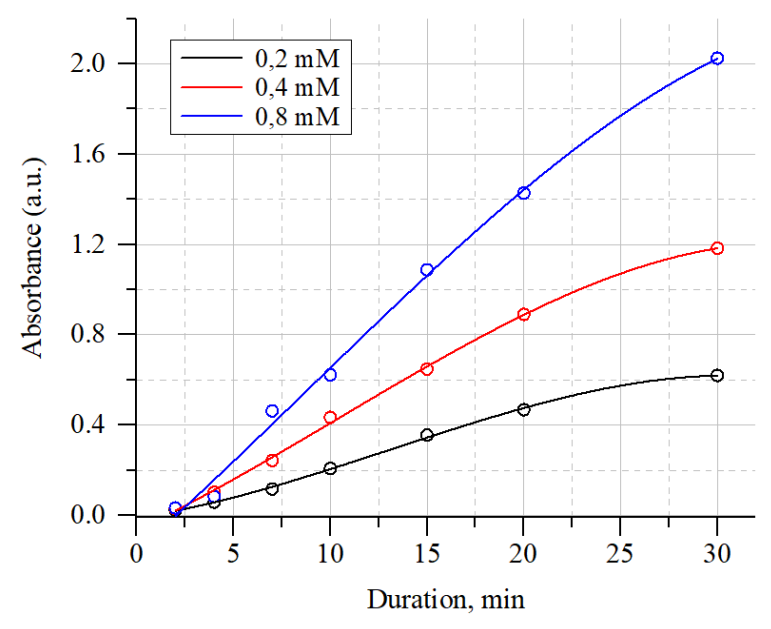

Fig. 4. UV-vis absorption spectrum of AgNPs over time depending on the concentration of $\mathrm{AgNO}_{3}\left(\mathrm{mmol} \cdot 1^{-1}\right)$

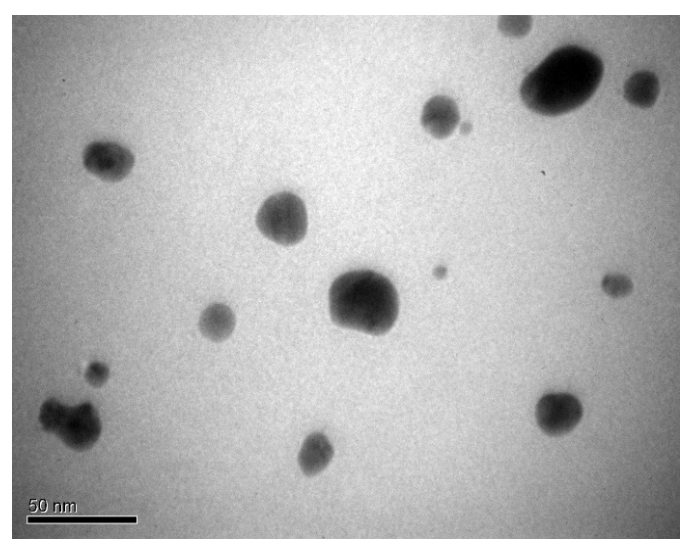

a)

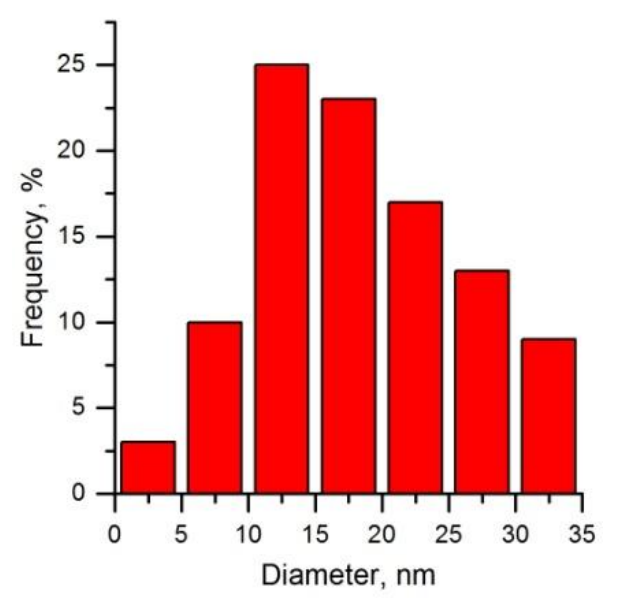

a')

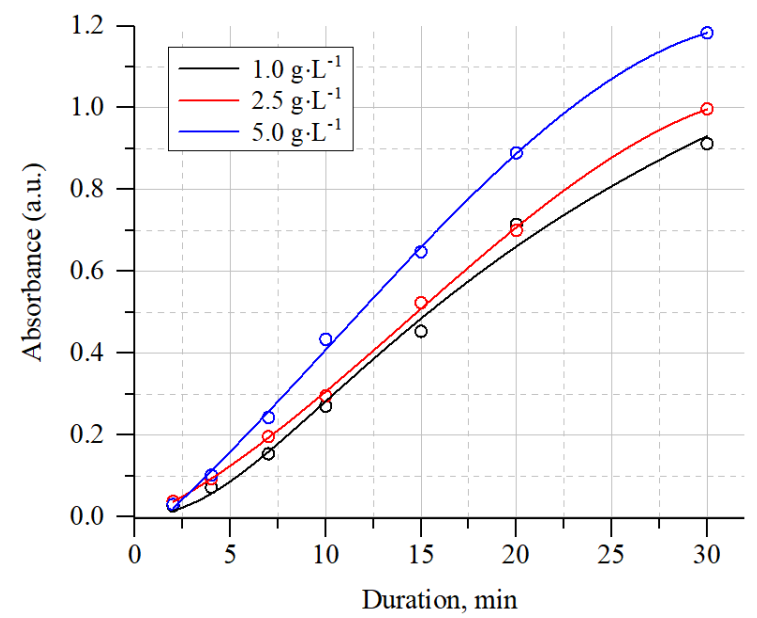

Fig/ 5. UV-Vis absorption spectrum of AgNPs over time depending on NaPA concentration

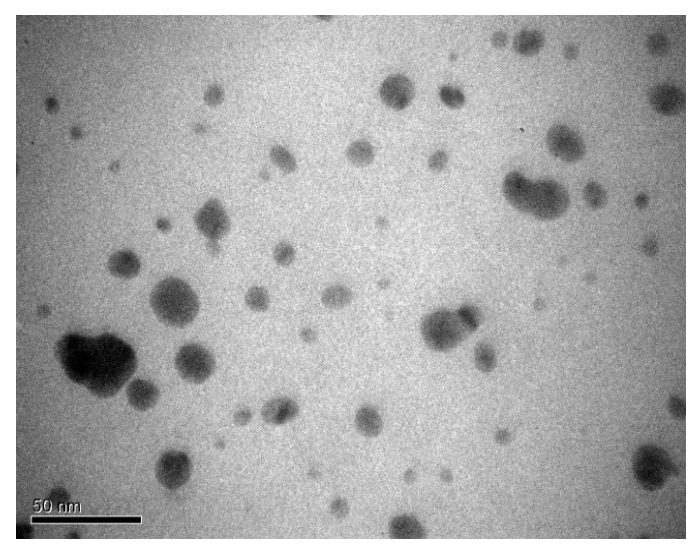

b)

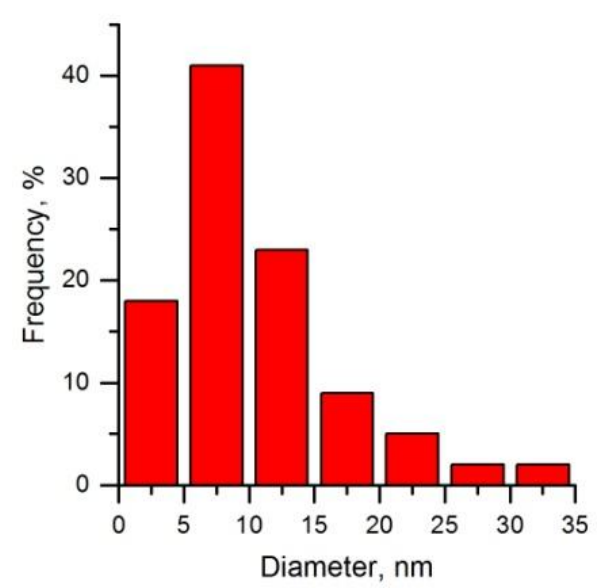

$\left.b^{\prime}\right)$

Fig. 6. TEM images (a, b) and the size distribution histograms $\left(a^{\prime}, b^{\prime}\right)$ of AuNPs, synthesized in solution $0,4 \mathrm{mM} \mathrm{AgNO}_{3}$ at $1\left(\mathrm{a}, \mathrm{a}^{\prime}\right)$ and $5\left(\mathrm{~b}, \mathrm{~b}^{\prime}\right) \mathrm{g} \cdot \mathrm{L}^{-1} \mathrm{NaPA}$ concentration 


\section{Disinfecting (antimicrobial) properties of silver nanoparticles solutions against} bacteria $E$. coli and $S$. aureus

\begin{tabular}{|c|c|c|c|c|c|c|c|c|}
\hline Strain of microorganisms & \multicolumn{4}{|c|}{ Escherichia coli } & \multicolumn{4}{|c|}{ Staphylococcus aureus } \\
\hline Exposure time, hours & 1 & 6 & 18 & 48 & 1 & 6 & 18 & 48 \\
\hline Number of microorganisms, $\mathrm{CFU} / \mathrm{cm}^{3}$ & 110 & 0 & 0 & 0 & 230 & 60 & 0 & 0 \\
\hline Disinfecting action & - & + & + & + & - & - & + & + \\
\hline
\end{tabular}

Notes: CFU/ $\mathrm{cm}^{3}$ - the number of colony-forming units in $1 \mathrm{~cm}^{3}$ of solution; + pronounced bactericidal action (no growth of bacteria); - no bactericidal action (there is a growth of bacteria).

With increasing NaPA concentration, there is a slight increase in the rate of synthesis of AgNPs (Fig. 5) and a tendency to decrease in their size (Fig. 6). The latter is due to the inhibition by the aggregation of nanoparticles in more concentrated solutions of surfactant.

The bactericidal effect of AgNPs was manifested after 6 hours of contact with the studied microorganisms: for $E$. coli it was absolute, $S$. aureus lost its pathogenic properties, and the number of microorganisms decreased by $73.9 \%$ (Table 2). Complete cessation of $S$. aureus growth was observed after 18 hours of exposure.

\section{Conclusions}

Galvanic substitution under ultrasound is one of the directions of intensification of "green" synthesis of metal nanoparticles. Under ultrasound, using magnesium as a sacrificial metal and sodium polyacrylate as a surfactant the colloidal solutions of AgNPs with a maximum absorption at $410 \mathrm{~nm}$ in the UV-vis spectra was obtained. The sizes of nanoparticles in a wide range of precursor concentrations and process duration are less than $30 \mathrm{~nm}$. The rate of AgNPs synthesis is almost proportional to the concentration of $\mathrm{AgNO}_{3}$ in the solution, while the effect of NaPA concentration is negligible. The latter one affects the size of nanoparticles - with the increasing concentration of surfactant there is a tendency to decrease. Simultaneous exposure to the surfactant and ultrasound prevents the deposition of silver on the magnesium surface, which provides the consumption of sacrificial metal almost exclusively on the synthesis of AgNPs. The synthesized nanoparticles efficiently demonstrated a bactericide effect on Escherichia coli and Staphylococcus aureus.

\section{Acknowledgments}

This work was carried out with the partial financial support of the National Research Foundation of Ukraine. Agreement 165/02.2020 (No 0120U105247 "Design of polyfunctional nanostructured mono- and bimetals with electrocatalytic and antimicrobial properties").

\section{References}

[1] Brankovic S.: Electrochem. Soc. Interface, 2018, 27, 57. https://doi.org/10.1149/2.F05182if

[2] Papaderakis A., Mintsouli I., Georgieva J., Sotiropoulo S.: Catalysts, 2017, 7, 80. https://doi.org/10.3390/catal7030080

[3] Kuntyi O., Zozulya G., Shepida M.: Voprosy Khimii i Khimicheskoi Tekhnologii, 2020, 4, 5.

https://doi.org/10.32434/0321-4095-2020-131-4-5-15

[4] Lahiri A., Kobayashi S.: Surf. Eng., 2016, 32, 321.

https://doi.org/10.1179/1743294415Y.0000000060

[5] Kuntyi O., Zozulya G., Shepida M., Nichkalo S.: Voprosy

Khimii i Khimicheskoi Tekhnologii, 2019, 3, 74.

https://doi.org/10.32434/0321-4095-2019-124-3-74-82

[6] Kuntyi O., Shepida M., Sus L. et al.: Chem. Chem. Technol., 2018, 12, 305. https://doi.org/10.23939/chcht12.03.305

[7] Niu K., Kulinich S., Yang J. et al.: Chem. Eur. J., 2012, 18, 4234. https://doi.org/10.1002/chem.201102544

[8] Oloye O., Tang C., Du A. et al.: Nanoscale, 2019, 11, 9705. https://doi.org/10.1039/c9nr02458a

[9] Silva A., Rodrigues T., Haigh S., Camargo P.: Chem. Comm., 2017, 53, 7135. https://doi.org/10.1039/C7CC02352A

[10] Lu F., Xin H., Xia W. et al.: ACS Cent. Sci., 2018, 4, 1742. https://doi.org/10.1021/acscentsci.8b00778

[11] Chee S., Tan S., Baraissov Z. et al.: Nat. Commun., 2017, 53,

1224. https://doi.org/10.1038/s41467-017-01175-2

[12] Mancier V., Rousse C., Dille J., Fricoteaux P.: Ultrason.

Sonochem., 2010, 17, 690.

https://doi.org/10.1016/j.ultsonch.2009.12.009

[13] Liu J., Hu M., Song Y. et al.: Synth. Met., 2014, 187, 185. https://doi.org/10.1016/j.synthmet.2013.10.034

[14] Pienpinijtham P., Sornprasit P., Wongravee K. et al.: RSC

Adv., 2015, 5, 78315. https://doi.org/10.1039/c5ra11193e

[15] Wu C., Mosher B., Zeng T.: Chem. Mater., 2006, 18, 2925. https://doi.org/10.1021/cm052400x

[16] Farsadrooh M., Noroozifar M., Modarresi-Alam A., Saravani

H.: Ultrason. Sonochem., 2019, 51, 478.

https://doi.org/10.1016/j.ultsonch.2018.06.011

[17] Wu C., Mosher B., Zeng T.: J. Nanosci. Nanotechnol., 2008, 8, 386. https://doi.org/10.1166/jnn.2008.18144

[18] Douk S., Saravani H., Farsadrooh M., Noroozifar M.: Ultrason. Sonochem., 2019, 58, 104616.

https://doi.org/10.1016/j.ultsonch.2019.104616 
[19] Zheng H., Matseke M., Munonde T.: Ultrason. Sonochem., 2019, 57, 166. https://doi.org/10.1016/j.ultsonch.2019.05.023 [20] Rousse C., Josse J., Mancier V. et al.: RSC Adv., 2016, 6, 50933. https://doi.org/10.1039/c6ra07002g

[21] Sun Z., Masa J., Xia W. et al.: ACS Catal., 2012, 2, 1647. https://doi.org/10.1021/cs300187z

[22] Lee E., Jang J., Matin M., Kwon Y.: Ultrason. Sonochem., 2014, 21, 317. https://doi.org/10.1016/j.ultsonch.2013.05.006

[23] Zapata-Fernández J., Gochi-Ponce Y., Salazar-Gastélum M. et al.: Int. J. Hydrogen Energy, 2017, 42, 9806.

https://doi.org/10.1016/j.ijhydene.2017.02.057

[24] Gherasim O., Puiu R., Bîrca A. et al.: Nanomaterials, 2020, 10, 2318. https://doi.org/10.3390/nano10112318

[25] Lee S., Jun B.: Int. J. Mol. Sci., 2019, 20, 865.

https://doi.org/10.3390/ijms20040865

[26] Jeong Y., Lim D., Choi J.: Adv. Mater. Sci. Eng., 2014, 2014,

763807. https://doi.org/10.1155/2014/763807

[27] Cheon J., Kim S., Rhee Y. et al.: Int. J. Nanomed., 2019, 14,

2773. https://doi.org/10.2147/IJN.S196472

[28] Haider A., Kang I.: Adv. Mater. Sci. Eng., 2015, 2015, 165257. https://doi.org/10.1155/2015/165257

[29] Calderón-Jiménez B., Johnson M. et al.: Front. Chem., 2017, 5, 1. https://doi.org/10.3389/fchem.2017.00006

[30] Liu G., Ma X., Sun X. et al.: Adv. Mater. Sci. Eng., 2018,

2018, 3758161. https://doi.org/10.1155/2018/3758161

[31] Srikar S., Giri D., Pal D. et al.: Green Sustain. Chem., 2016, 6, 34. https://doi.org/10.4236/gsc.2016.61004

[32] Some S., Sen I., Mandal A. et al.: Mater. Res. Express, 2018, 6, 012001. https://doi.org/10.1088/2053-1591/aae23e

[33] Kuntyi O., Kytsya A., Mertsalo I. et al.: Colloid Polym. Sci., 2019, 297, 689. https://doi.org/10.1007/s00396-019-04488-4

[34] Kuntyi O., Mazur A.; Kytsya A. et al.: Micro Nano Lett., 2020, 15, 802. https://doi.org/10.1049/mnl.2020.0195

[35] Skiba M., Vorobyova V., Kovalenko I., Shakun A.: Chem.

Chem. Technol., 2020, 14, 297.

https://doi.org/10.23939/chcht14.03.297

[36] Pollet B.: Int. J. Hydrogen Energy, 2010, 35, 11986.

https://doi.org/10.1016/j.ijhydene.2010.08.021
[37] He C., Liu L.; Fang Z. et al.: Ultrason. Sonochem., 2014, 21, 542. https://doi.org/10.1016/j.ultsonch.2013.09.003

[38] Kuntyi O., Zozulya G., Kurilets O.: Russ. J. Non-Ferr. Met., 2007, 48, 413. https://doi.org/10.3103/S1067821207060077

[39] Kuntyi O., Dobrovetska O., Korniy S. et al.: Chem. Chem. Technol., 2014, 8, 193. https://doi.org/10.23939/chcht08.02.193 [40] Kuntyi O., Masyk O., Minakova R.: Mater. Sci., 2004, 40, 428. https://doi.org/10.1007/s11003-005-0013-1

[41] Yavorskiy V., Sukhatskiy Y., Znak Z., Mnykh R.: Chem. Chem. Technol., 2016, 10, 507.

https://doi.org/10.23939/chcht10.04.507

Received: December 17, 2020 / Revised: December 28, 2020 / Accepted: March 12, 2021

\section{СИНТЕЗ НАНОЧАСТИНОК СРІБЛА ГАЛЬВАНІЧНИМ ЗАМШЩЕННЯМ НА МАІННÏ В РОЗЧИНАХ НАТРІЮ ПОЛІАКРИЛАТУ В УЛЬТРАЗВУЦІ}

Анотація. Досліджено “зелений” синтез наночастинок срібла (AgNPs) внаслідок гальванічного заміщення (ГЗ) на магній у розчинах натрію поліакрилату (NaPA) в ультразвуці (22 кГи). Запропоновано механізм спільної діі ГЗ та ультразвуку з утворенням AgNPs. Визначено, шчо синтезовані розчини AgNPs характеризуються максимумом поглинання за 410 нм, значення якого не залежить від концентрацій прекурсорів ( $\mathrm{AgNO}_{3}$ ma NaPA) i тривалості прочесу. Розміри наночастинок, що мають сферичну форму, не перевищують 30 нм. Встановлено, що зі збільшенням концентрачії ПАР спостерігається тендениія до зменшення їх розмірів. Швидкість синтезу AgNPs збільшується майже пропориійно концентрації $\mathrm{AgNO}_{3}$ у розчині, тоді як вплив концентрачії NaPA незначний. Показано ефективну бактерицидну дію синтезованих наночастинок на Escherichia coli ma Staphylococcus aureus.

Ключові слова: наночастинки срібла, ультразвук, гальванічне заміщення; магній, натрію поліакрилат. 